\title{
Perbandingan Produksi Dan Pendapatan Usahatani Padi Sawah di Desa Saentis Kecamatan Percut Sei Tuan Kabupaten Deli Serdang
}

\author{
${ }^{1}$ Ramses Simbolon*, ${ }^{2}$ Ari Kristifan Lumban Gaol \\ ${ }^{1,2}$ Prodi Agribisnis, Fakultas Pertanian, Unika St. Thomas \\ Email : ramsessimbolon.agb@gmail.com
}

\begin{abstract}
Abstrak
Penelitian ini bertujuan untuk (1) Untuk mengetahui besar produktivitas yang dihasilkan oleh petani Penangkar Benih dan Kelompok Tani Subur di Desa Saentis, (2) Untuk mengetahui besar biaya produksi per hektar yang dikeluarkan petani Penangkar Benih dan Kelompok Tani Suburdi Desa Saentis, dan (3) Untuk mengetahui besar pendapatan bersih per hektar petani Penangkar Benih dan Kelompok Tani Subur di Desa Saentis. Populasi dalam penelitian ini adalah petani penangkar benih yang mengusahakan padi sawah yang telah menghasilkan (panen) di 10 Ha Desa Saentis. Penentuan sampel ditentukan secara sampling jenuh (sensus) yaitu metode penarikan sampel bila semua anggota populasi dijadikan sebagai sampel yaitu 20 petani. Dari hasil penelitian diperoleh kesimpulan sebagai berikut: (1) Produktivitas usahatani padi sawah petani penangkar benih lebih besar dibandingkan dengan petani kelompok tani subur. Produktivitas petani penangkar benih sebesar 7,34 ton/ha, sedangkan petani kelompok tani subur sebesar 5,78 ton/ha, (2) Biaya produksi usahatani padi sawah petani penangkar benih lebih besar dibandingkan dengan petani kelompok tani subur. Biaya produksi petani penangkar benih sebesar Rp. 11.633.733/ha/mt, sedangkan petani kelompok tani subur sebesar Rp. 11.370.902/ha/mt, dan (3) Pendapatan bersih usahatani padi sawah petani penangkar benih lebih besar dibandingkan dengan petani kelompok tani subur. Pendapatan bersih usahatani padi sawah petani penangkar benih sebesar Rp. 21.360.266/ha/mt, sedangkan petani kelompok tani subur sebesar Rp. 12.977.502/ha/mt.
\end{abstract}

Keyword : Produksi, Pendapatan Usahatani, Padi

\begin{abstract}
This research aim to (1) determine the amount of productivity produced by the breeders and the Subur farmer groups in Saentis Village, (2) determine the amount of production costs per hectare incurred by the seed breeders and the Subur famer groups in Saentis Village, and (3) determine the amount of net incoe per hectare of seed breeders and the Subur famer in Saentis Village Population in this research were seed-breeding farmers who cultivade paddy fields that had produced (harvested) in 10 hectares of Santis Village. Sampling was determined by census, namely the sampling method when all members of the population were sampled. The results of this research, were obtained: (1) The productivity of lowland rice farming by seed breeders was greater than that of the Subur farmer groups. The productivity os seed breeder farmers in 7.34 ton/ha, while Subur farmer groups are 5.78 ton/ha. (2) The production costs of lowland rice farming of seed breeders are higer than those of Subur farmer groups. The production cost for seed breeder famers is Rp. 11,633,733/ha/mt, while the Subur farmer group famers were Rp. 11,370,902/ha/mt. (3) Net income of lowland rice farming by seed breeders is greater than that of Subur farmer groups. The net income of lowland rice farming by seed breeders is Rp. 21,360,266/ha/mt, while Subur farmer group famers are Rp/ 12,977,502/ha/mt.
\end{abstract}

\section{Keyword : Production, Farmer Income, Rice}

\section{PENDAHULUAN}

Padi merupakan sumber makanan pokok penduduk Indonesia. Besarnya bahan makanan padi atau beras tentu berbanding lurus dengan jumlah penduduk di Indonesia. Jika jumlah penduduk di Indonesia meningkat maka permintaan kebutuhan beras (hasil olahan padi) meningkat. Begitu pula sebaliknya, permintaan beras akan menurun jika jumlah penduduk di Indonesia menurun. Hal ini berlaku jika kebutuhan beras hanya untuk konsumsi saja, bukan hal lain, seperti untuk diekspor baik dalam bentuk bahan baku atau hasil olahan (Soekartawi, 1995).

Dalam bidang ketahanan pangan nasional, beras merupakan komoditi strategis yang mempunyai pengaruh besar terhadap aspek sosial, ekonomi, politik dan keamanan bangsa Indonesia. Sebagai bahan makanan pokok, beras telah menyumbangkan lebih dari 55\% terhadap kebutuhan konsumsi energi dan protein masyarakat. Apabila terjadi kekurangan bahan makanan yang lain, beras dapat mensuplai kebutuhan konsumsi masyarakat. Menjamin ketersediaan beras bagi masyarakat berpengaruh terhadap terpenuhinya tingkat asupan gizi yang dibutuhkan masyarakat yang merupakan hak azasi manusia. Untuk mewujudkan hal itu maka diperlukan upaya swasembada pangan (Sumodiningrat, 2000).

Peningkatan produksi padi sangat dipengaruhi oleh luas lahan yang digunakan. Ketersediaan lahan yang luas dapat menjamin peningkatan produksi, alan tetapi dengan lahan yang 
terbatas, akibat perkembangan penduduk yang semakin meningkat, peningkatan produksi padi harus dilakukan dengan cara intensifikasi yaitu pemanfaatan sarana produksi yang optimum untuk menghasilkan produksi yang maksimum (Putro, 2010).

Tabel 1. Perkembangan Luas Panen, Produksi, dan Produktivitas Padi Sawah di Sumatera Utara, Tahun 2013 - 2017

\begin{tabular}{|c|c|c|c|}
\hline Tahun & $\begin{array}{c}\text { Luas } \\
\text { Panen } \\
\text { (Ha) }\end{array}$ & $\begin{array}{c}\text { Produksi } \\
\text { (Ton) }\end{array}$ & $\begin{array}{c}\text { Produktivitas } \\
\text { (Ton/Ha) }\end{array}$ \\
\hline 2013 & 742.968 & 3.727 .249 & 5,01 \\
2014 & 676.724 & 3.490 .516 & 5,16 \\
2015 & 731.811 & 3.868 .880 & 5,29 \\
2016 & 826.695 & 4.387 .035 & 5,31 \\
2017 & 864.283 & 4.669 .778 & 5,41 \\
\hline
\end{tabular}

Sumber : Badan Pusat Statistik Tahun 2018

Dari Tabel 1 dapat diketahui Luas lahan cenderung meningkat, seiring bertambah luas lahan. Provinsi Sumatera Utara pada tahun 2017 memiliki luas panen, produksi, dan produktivitas yang paling besar dibandingkan tahun 2013 - 2016 dengan luas lahan sebesar 864.283 Ha, jumlah produksi sebesar 4.669.778 Ton dan produktivitas sebesar 5,41 Ton/Ha. Diharapkan jumlah produksi padi sawah yang dihasilkan dapat terus mengalami peningkatan dari tahun ke tahun.

Tabel 2. Perkembangan Luas Panen, Produksi, dan Produktivitas Padi Sawah di Kabupaten Deli Serdang, Tahun 2013-2017

\begin{tabular}{|c|c|c|c|}
\hline Tahun & $\begin{array}{c}\text { Luas } \\
\text { Panen } \\
\text { (Ha) }\end{array}$ & $\begin{array}{c}\text { Produksi } \\
\text { (Ton) }\end{array}$ & $\begin{array}{c}\text { Produktivitas } \\
\text { (Ton/Ha) }\end{array}$ \\
\hline 2013 & 79.741 & 448.462 & 5,624 \\
2014 & 74.481 & 423.066 & 5,680 \\
2015 & 75.105 & 425.588 & 5,667 \\
2016 & 81.955 & 489.766 & 5,976 \\
2017 & 88.881 & 512.321 & 5,764 \\
\hline
\end{tabular}

Sumber : Badan Pusat Statistik Tahun 2018

Dari Tabel 2 dapat diketahui bahwa Luas lahan panen dan produksi mengalami fluktuasi. Kabupaten Deli Serdang pada tahun 2017 memiliki luas panen dan produksi yang paling besar dibandingkan tahun 2013 - 2016 dengan luas lahan 88.881 Ha dan Produksi 512.312 Ton. Diharapkan jumlah produksi padi sawah yang dihasilkan dapat terus mengalami peningkatan dari tahun ke tahun.

Tabel 3. Perkembangan Luas Panen, Produksi, dan Produktivitas Padi Sawah di Kecamatan Percut Sei Tuan, Tahun 2013 - 2017

\begin{tabular}{|c|c|c|c|}
\hline Tahun & $\begin{array}{c}\text { Luas } \\
\text { Panen } \\
(\mathrm{Ha})\end{array}$ & $\begin{array}{c}\text { Produksi } \\
\text { (Ton) }\end{array}$ & $\begin{array}{c}\text { Produktivitas } \\
\text { (Ton/Ha) }\end{array}$ \\
\hline 2013 & 10.794 & 71.47 & 6,621 \\
2014 & 10.698 & 70.65 & 6,603 \\
2015 & 9.303 & 52.09 & 5,600 \\
2016 & 3.408 & 48.19 & 1,414 \\
2017 & 9.682 & 58.04 & 5,990 \\
\hline
\end{tabular}

Sumber : Badan Pusat Statistik Tahun 2018

Dari Tabel 3 dapat diketahui bahwa Kecamatan Percut Sei Tuan pada tahun 2013 memiliki luas panen, produksi dan produktivitas yang paling besar dibandingkan 2014 - 2017 dengan luas lahan 10.794, produksi 71.471 ton dan produktivitas 6.621 Ton/Ha. Desa saentis merupakan salah satu desa di Kecamatan Percut Sei Tuan yang mayoritas bermata pencarian sebagai petani padi sawah, dimana hasil produksi padi yang diperoleh selain untuk dijual dan sebagian juga dikonsumsi oleh keluarga. Jumlah produksi padi sawah mengalami penurunan, hal ini disebabkan oleh penggunaan faktor produksi seperti luas lahan, pemberian pupuk, dan penggunaan pestisida yang mulai berkurang. Belum tentu pasti dari mana faktor yang menyebabkan terjadinya penurunan produksi padi sawah dan salah satu faktornya adalah luas lahan.

\section{METODE PENELITIAN}

Daerah penelitian ditentukan secara "Purposive Sampling" (sengaja) yaitu teknik untuk menentukan sampel penelitian dengan beberapa pertimbangan tertentu yang bertujuan agar data yang diperoleh nanti bisa lebih representif, di Desa Saentis, Kecamatan Percut Sei Tuan, Kabupaten Deli Serdang. Adapun dasar pertimbangan dalam penentuan daerah penelitian ini adalah karena penduduk di daerah mengusahakan tanaman padi sawah dan penangkaran benih serta mempertimbangkan jarak dan waktu ke daerah penelitian.

Populasi dalam penelitian ini adalah petani penangkar benih yang mengusahakan padi sawah yang telah menghasilkan (panen) di $10 \mathrm{Ha}$ Desa Saentis. Penentuan sampel ditentukan secara sampling jenuh (sensus) yaitu metode penarikan sampel bila semua anggota populasi dijadikan sebagai sampel yaitu 20 petani.

Populasi kelompok tani subur yang mengusahakan padi sawah yang telah menghasilkan di Desa Saentis sebanyak 120 orang. Metode penentuan sampel dilakukan dengan secara purposive sampling.

Data yang dikumpulkan dalam penelitian ini terdiri dari data primer dan data sekunder. Data primer diperoleh dari hasil wawancara langsung dengan petani dengan menggunakan alat bantu kuesioner. Data sekunder diperoleh dari studi kepustakaan baik berupa buku, jurnal, maupun data 
statistika dari instansi terkait yang berhubungan dengan topik penelitian ini.

Untuk analisa tujuan pertama, digunakan penghitungan dengan menggunakan rumus :

$$
\text { Produktivitas }=\frac{\text { Output }}{\text { Input }}
$$

Untuk analisa tujuan kedua, menghitung besar biaya produksi usahatani penangkar benih dan petani padi sebar dengan cara :

Dimana :

$$
\mathbf{T C}=\mathbf{F C}+\mathrm{VC}
$$

$$
\begin{array}{ll}
\mathrm{TC} & =\text { Total Cost / Biaya Total (Rp) } \\
\mathrm{FC} & =\text { Fixed Cost / Biaya Tetap (Rp) } \\
\mathrm{VC} & =\text { Variable Cost / Biaya Variabel (Rp) }
\end{array}
$$

Untuk analisa tujuan ketiga, menghitung pendapatan usahatani petani padi sawah dan petani penangkar benih dihitung dengan rumus: pendapatan adalah penerimaan usaha dikurangi total biaya usaha. Penerimaan adalah hasil parkalian antara harga jual dengan jumlah yang terjual.

$$
\mathbf{T R}=\mathbf{P} \times \mathbf{Q}
$$

dimana

$\mathrm{TR}=$ Total penerimaan $(\mathrm{Rp})$

$\mathrm{P} \quad=$ Harga jual $(\mathrm{Rp})$

$\mathrm{Q} \quad=$ Jumlah yang terjual $(\mathrm{Rp})$

Sementara itu, pendapatan dihitung dengan rumus sebagai berikut:

Dimana :

$$
\boldsymbol{\pi}=\mathbf{T R}-\mathbf{T C}
$$

$\pi \quad=$ Total pendapatan $(\mathrm{Rp})$

TR = Total Penerimaan usahatani (Rp)

$\mathrm{TC}=$ Total biaya usahatani $(\mathrm{Rp})$

Untuk mengetahui perbedaan produktivitas dilakukan uji beda rataan dengan menggunakan uji t dengan menggunakan rumus

$$
\mathrm{t}_{\text {hitung }}=\frac{\overline{\mathrm{x}}_{1}-\overline{\mathrm{x}}_{2}}{\mathrm{~S} \sqrt{\frac{1}{\mathrm{n}_{1}}+\frac{1}{\mathrm{n}_{2}}}}
$$

Dimana:

$\mathrm{S}$ = Simpangan Baku

$\mathrm{n}_{1}=$ Besar sampel petani padi sawah penangkar benih

$\mathrm{n}_{2}=$ Besar sampel petani padi sawah kelompok tani subur

$\mathrm{x}_{1}=$ Produktivitas petani padi sawah penangkar benih

$\mathrm{x}_{2}=$ Produktivitas petani padi sawah kelompok tani subur

Hipotesis (1) yang akan diuji :

$H_{0}$ : Produktivitas petani padi sawah penangkar benih sama dengan petani kelompok tani subur

$\mathrm{H}_{1}$ : Produktivitas petani padi sawah penangkar benih lebih besar dibandingkan petani kelompok tani subur.

Kriteria pengambilan keputusan :

Tolak $\mathrm{H}_{0}$ jika : $\mathrm{t}_{\text {hit }}>\mathrm{t}_{\text {tabel }}$
Terima $\mathrm{H}_{0}$ jika : $\mathrm{t}_{\text {hit }}<\mathrm{t}_{\text {tabel }}$

Untuk mengetahui perbedaan biaya produksi dilakukan uji beda rataan dengan menggunakan uji t dengan menggunakan rumus :

$$
\mathrm{t}_{\text {hitung }}=\frac{\overline{\mathrm{X}}_{1}-\overline{\mathrm{X}}_{2}}{\mathrm{~S} \sqrt{\frac{1}{\mathrm{n}_{1}}+\frac{1}{\mathrm{n}_{2}}}}
$$

Dimana:

$\mathrm{S}$ = Simpangan Baku

$\mathrm{n}_{1}=$ Besar sampel petani padi sawah penangkar benih

$\mathrm{n}_{2}=$ Besar sampel petani padi sawah kelompok tani subur

$\mathrm{x}_{1}=$ Biaya produksi petani padi sawah penangkar benih

$\mathrm{x}_{2}=$ Biaya produksi petani padi sawah kelompok tani subur

Hipotesis (2) yang akan diuji :

$H_{0}$ : Biaya produksi petani padi sawah penangkar benih sama dengan petani kelompok tani subur

$\mathrm{H}_{1}$ : Biaya produksi petani padi sawah penangkar benih lebih besar dibandingkan petani kelompok tani subur.

Kriteria pengambilan keputusan :

Tolak $\mathrm{H}_{0}$ jika : $\mathrm{t}_{\text {hit }}>\mathrm{t}_{\text {tabel }}$

Terima $\mathrm{H}_{0}$ jika : $\mathrm{t}_{\text {hit }}<\mathrm{t}_{\text {tabel }}$ (Sudjana, 1989).

Untuk mengetahui pendapatan bersih dilakukan uji beda rataan dengan menggunakan uji t dengan menggunakan rumus :

$$
\mathrm{t}_{\text {hitung }}=\frac{\overline{\mathrm{X}}_{1}-\overline{\mathrm{X}}_{2}}{\mathrm{~S} \sqrt{\frac{1}{\mathrm{n}_{1}}+\frac{1}{\mathrm{n}_{2}}}}
$$

Dimana:

$\mathrm{S}$ = Simpangan Baku

$\mathrm{n}_{1}=$ Besar sampel petani padi sawah penangkar benih

$\mathrm{n}_{2}=$ Besar sampel petani padi sawah kelompok tani subur

$\mathrm{x}_{1}=$ Pendapatan bersih petani padi sawah penangkar benih

$\mathrm{x}_{2}=$ Pendapatan bersih petani padi sawah kelompok tani subur

Hipotesis (3) yang akan diuji :

$H_{0}$ : Pendapatan bersih petani padi sawah penangkar benih tidak berbeda dengan petani kelompok tani subur

$\mathrm{H}_{1}$ : Pendapatan bersih petani padi sawah penangkar benih lebih besar dibandingkan petani kelompok tani subur.

Kriteria pengambilan keputusan :

Tolak $\mathrm{H}_{0}$ jika : $t_{\text {hit }}>\mathrm{t}_{\text {tabel }}$

Terima $\mathrm{H}_{0}$ jika : $\mathrm{t}_{\text {hit }}<\mathrm{t}_{\text {tabel }}$ (Sudjana, 1989).

Dalam uji $\mathrm{t}$ digunakan dengan bantuan program SPSS versi 22. 
Penentuan lokasi penelitian ditentukan secara sengaja atau purposif. Lokasi penelitian yang dipilih adalah Provinsi Sumatera Utara'

Data yang digunakan dalam penelitian ini adalah data sekunder, yaitu data yang mendukung diperoleh dari Badan Pusat Statistik (BPS) Sumatera Utara, Dinas Perindustrian dan Perdagangan Sumatera Utara, dan Dinas Ketahanan Pangan Sumatera Utara. Data penelitian ini merupakan data deret waktu (time series) dari tahun 1988-2017. Beberapa data yang dibutuhkan dalam penelitian meliputi permintaan beras, harga beras, harga ketela pohon, harga ubi kayu, pendapatan populasi per kapita, dan jumlah populasi.

\section{HASIL DAN PEMBAHASAN}

\section{A. Produksi dan Produktivitas Usahatani Padi}

Tanaman padi sawah mulai dari penanaman sampai dengan pemanenan membutuhkan waktu 4 bulan. Ini berarti di dalam waktu 4 bulan tanaman padi sawah sudah siap dipanen. Produksi padi sawah yang dihasilkan ditentukan oleh luas lahan dan keadaan pertumbuhan tanaman selama pertanaman. Di daerah penelitian, petani melakukan dua musim tanam. Produksi dalam hal ini adalah gabah (ton) yang diperoleh selama satu musim tanam, sedangkan produktivitas adalah kemampuan dari satuan luas lahan usahatani untuk memberikan hasil sebagai balas jasa atas sejumlah pengorbanan faktor-faktor produksi yang telah diberikan. Produksi dan produktivitas usahatani padi sawah di daerah penelitian dapat dilihat pada Tabel 4.

Tabel 4. Luas Lahan, Produksi, Produktivitas Usahatani Padi Sawah di Daerah Penelitian pada Musim Tanam II, Tahun 2019

\begin{tabular}{|c|l|c|c|}
\hline No & \multicolumn{1}{|c|}{ Uraian } & $\begin{array}{c}\text { Petani } \\
\text { Penangkar }\end{array}$ & $\begin{array}{c}\text { Kelompok } \\
\text { Tani Subur }\end{array}$ \\
\hline 1 & Luas Lahan Rata Rata (Ha) & 0,5 & 0,38 \\
2 & Produksi (Ton/Petani) & 3,67 & 2,20 \\
3 & Harga (Rp/Kg) & Rp4.500 & Rp4.300 \\
4 & Produktivitas (Ton/Ha) & 7,34 & 5,78 \\
\hline
\end{tabular}

Dari Tabel 4 dapat dilihat bahwa produksi rata-rata usahatani padi sawah petani penangkar sebesar 3,67 Ton sedangkan kelompok tani subur sebesar 2,20 Ton lebih kecil dibandingkan produksi petani penangkar. Produktivitas rata-rata usahatani petani penangkar sebesar 7,34 Ton/Hektar/Mt lebih besar dari produkstivitas rata-rata usahatani kelompok subur subur sebesesar 5,78 Ton/Hektar/Mt.

Hasil penelitian ini menunjukkan bahwa Produktivitas usahatani padi sawah di daerah penelitian sudah tergolong besar karena berada di atas produktivitas potensial yang ditetapkan oleh Dinas Pertanian Kabupaten Deli Serdang 5,8
Ton/Hektar/Mt. Hal ini disebabkan petani telah mengikuti semua anjuran yang telah diberikan oleh penyuluh pertanian. Petani melakukan pemupukan sesuai dengan dosis anjuran dan melakukan pengendalian hama secara teratur, sehingga pengaruhnya terhadap penurunan produksi usahatani padi sawah tergolong sangat kecil. Disamping itu penggunaan benih berlabel ungu pada penangkar benih dan label biru untuk kelompok tani subur mempengaruhi jumlah produksi, karena benih berlabel ungu memiliki produktivitas lebih besar dibanding dengan benih berlabel biru. Secara keseluruhan usahatani padi sawah di daerah penelitian memiliki sistem irigasi yang baik, sehingga dapat memenuhi kebutuhan air selama pertanaman padi sawah. Selain berdasarkan kondisi tanah, irigasi, dan serangan hama, produktivitas yang besar di daerah penelitian kemungkinan besar juga disebabkan oleh keaktifan petani dalam mengikuti penyuluhan pertanian. Hal ini memengaruhi pola pikir dan perilaku petani dalam melakukan usahatani padi yang pada akhirnya memengaruhi produksi dan produktivitasnya.

Sesuai dengan tujuan penelitian yaitu untuk melihat perbandingan Produktivitas usahatani padi sawah petani penangkar benih dengan petani kelompok tani subur, maka untuk membandingkan Produktivitas tersebut digunakan uji beda rata-rata dengan uji t.

Berdasasarkan uji t menggunakan SPSS uji rata rata (uji t) independent sampel t-test sebesar $7,568>2,009$. Sehingga dapat disimpulkan hipotesis $\mathrm{H}_{0}$ ditolak dan $\mathrm{H}_{1}$ diterima yang artinya produktivitas petani padi sawah penangkar benih lebih besar dibandingkan petani kelompok tani subur.

Produktivitas tanaman padi sawah petani penangkar benih lebih besar dibandingkan dengan petani kelompok tani subur. Perbedaan produksi yang dihasilkan oleh petani disebabkan karakteristik benih yang digunakan dan sistem penanaman, meskipun hama dan penyakit tanaman serta ketersediaan irigasi di kedua lokasi relatif tidak berbeda. Varietas benih yang digunakan oleh petani penangkar telah sesuai anjuran dinas pertanian, berbeda dengan benih yang digunakan petani kelompok tani subur yang cenderung tidak sesuai. Hasil produksi yang rendah pada petani kelompok tani subur disebabkan karena sebagian petani melakukan kegiatan budidaya dengan menggunakan benih yang tidak memiliki kelas serta tidak berlabel. Benih tersebut didapatkan petani dari hasil penanaman sebelumnya yang tidak ditujukan sebagai benih di awal penanaman.

Dalam pengelolaan usahatani padi sawah dilakukan beberapa proses dan dibutuhkan berbagai faktor-faktor produksi. Untuk lebih jelas dapat dilihat pada uraian berikut.

\section{Sarana Produksi}

Penggunaan sarana produksi pada usahatani 
padi sawah di daerah penelitian dapat dilihat pada Tabel 5.

Tabel 5. Rata-rata Penggunaan Sarana Produksi Usahatani Padi Sawah di Daerah Penelitian pada Musim Tanam II, Tahun 2019

\begin{tabular}{|c|c|c|c|c|c|}
\hline \multirow[b]{2}{*}{ No } & \multirow[b]{2}{*}{$\begin{array}{c}\text { Sarana } \\
\text { Produksi }\end{array}$} & \multicolumn{2}{|c|}{$\begin{array}{c}\text { Petani } \\
\text { Penangkar }\end{array}$} & \multicolumn{2}{|c|}{ Keltan Subur } \\
\hline & & $\begin{array}{c}\text { Per } \\
\text { Petani } \\
(0,5 \\
\text { Ha) }\end{array}$ & $\begin{array}{l}\text { Per } \\
\text { Hektar }\end{array}$ & $\begin{array}{c}\text { Per } \\
\text { Petani } \\
(0,38 \\
\mathrm{Ha})\end{array}$ & $\begin{array}{c}\text { Per } \\
\text { Hektar }\end{array}$ \\
\hline 1 & Benih $(\mathrm{kg})$ & 12,5 & 25 & 14,57 & 37,5 \\
\hline 2 & $\begin{array}{l}\text { Pupuk } \\
\text { - Urea (kg) } \\
\text { - SP-36 } \\
(\mathrm{kg}) \\
\text { - ZA (kg) } \\
\text { - Phonska } \\
(\mathrm{kg})\end{array}$ & $\begin{array}{r}62,6 \\
37,5 \\
112,5 \\
100\end{array}$ & $\begin{array}{r}125 \\
75 \\
225 \\
200\end{array}$ & $\begin{array}{l}48,59 \\
29,15 \\
87,46 \\
77,75\end{array}$ & $\begin{array}{r}125 \\
75 \\
225 \\
200\end{array}$ \\
\hline & Total & 325,1 & 650 & 257,52 & 662,5 \\
\hline 3 & $\begin{array}{l}\text { Pestisida } \\
\text { - Desis } \\
(\mathrm{ml}) \\
\text { - Antracol } \\
(\mathrm{kg}) \\
\text { - Bell (ml) } \\
\text { - Seltima } \\
(\mathrm{btl}) \\
\end{array}$ & $\begin{array}{r}100 \\
1 \\
250 \\
1\end{array}$ & $\begin{array}{r}200 \\
2 \\
500 \\
2\end{array}$ & $\begin{array}{r}77,75 \\
0,77 \\
194,37 \\
0,77\end{array}$ & $\begin{array}{r}200 \\
2 \\
500 \\
2\end{array}$ \\
\hline & Total & 352 & 704 & 273,66 & 704 \\
\hline
\end{tabular}

Tabel 5 menunjukkan bahwa rata-rata penggunaan benih petani penangkar sebesar 25

Tabel 6. Rata-rata Nilai Sarana Produksi Usahatani Padi Sawah di Daerah Penelitian pada Musim Tanam II, Tahun 2019

\begin{tabular}{|c|c|c|c|c|c|}
\hline \multirow[b]{2}{*}{ No } & \multirow{2}{*}{ Sarana Produksi } & \multicolumn{2}{|c|}{ Petani Penangkar } & \multicolumn{2}{|c|}{ Keltan Subur } \\
\hline & & Per Petani $(0,5 \mathrm{Ha})$ & Per Hektar & Per Petani $(0,38 \mathrm{Ha})$ & Per Hektar \\
\hline 1 & Benih & 175.000 & 350.000 & 174.938 & 450.000 \\
\hline 2 & $\begin{array}{l}\text { Pupuk } \\
\text { - Urea } \\
\text { - SP-36 } \\
\text { - ZA } \\
\text { - Phonsk }\end{array}$ & $\begin{array}{c}187.500 \\
131.250 \\
281.250 \\
350.000\end{array}$ & $\begin{array}{l}375.000 \\
262.500 \\
562.500 \\
700.000\end{array}$ & $\begin{array}{l}145.781 \\
102.047 \\
218.672 \\
272.125\end{array}$ & $\begin{array}{l}375.000 \\
262.500 \\
562.500 \\
700.000\end{array}$ \\
\hline & Sub Total & 949.750 & 1.900 .000 & 738.625 & 1.900 .000 \\
\hline 3 & $\begin{array}{l}\text { Pestisida } \\
\text { - Desis } \\
\text { - Antrcl } \\
\text { - Bell } \\
\text { - Sltima }\end{array}$ & $\begin{array}{r}60.000 \\
135.000 \\
375.000 \\
170.000\end{array}$ & $\begin{array}{l}120.000 \\
270.000 \\
750.000 \\
340.000\end{array}$ & $\begin{array}{r}46.650 \\
104.963 \\
291.563 \\
132.175\end{array}$ & $\begin{array}{l}120.000 \\
270.000 \\
750.000 \\
340.000\end{array}$ \\
\hline & Sub Total & 740.000 & 1.480 .000 & 575.351 & 1.480 .000 \\
\hline & Total & 1.864 .750 & 3.730 .000 & 1.448 .914 & 3.830 .000 \\
\hline
\end{tabular}

Tabel 6 menunjukkan bahwa biaya rata-rata sarana produksi benih petani penangkar benih sebesar Rp. 350.000 /hektar/mt sedangkan kelompok tani subur sebesar Rp 450.000 /hektar/mt. Biaya rata-rata sarana produksi pupuk penangkar benih dan kelompok tani adalah sama sebesar Rp. 1.900.000 /hektar/mt. Biaya rata-rata sarana produksi pestisida $\mathrm{kg} /$ hektar lebih kecil daripada rata-rata penggunaan benih kelompok tani subur. Hal ini tergolong cukup besar, dimana kebutuhan benih untuk setiap satu hektar berkisar antara $20-25 \mathrm{~kg}$ (Dinas Pertanian Deli Serdang, 2017). Penggunaan benih yang cukup besar kemungkinan disebabkan sebagian petani memprediksi ada sebagian dari semai yang mungkin nantinya mengalami kerusakan, sehingga petani memiliki bibit semai untuk dijadikan sulaman pada tanaman padi sawah yang kurang bagus pertumbuhannya. Penggunaan benih yang terlalu besar dapat mengakibatkan semakin meningkatnya biaya produksi usahatani.

Rata-rata penggunaan pupuk pada usahatani penangkar benih dan kelompok tani subur di tempat penelitian sama besar yaitu urea sebanyak $125 \mathrm{~kg} / \mathrm{ha}$, pupuk SP-36 sebanyak $75 \mathrm{~kg} / \mathrm{ha}$, pupuk ZA sebanyak $225 \mathrm{~kg} / \mathrm{ha}$ dan pupuk Phonska sebanyak $200 \mathrm{~kg} / \mathrm{ha}$. Penggunaan dosis pupuk di daerah penelitian masih belum sesuai dengan dosis anjuran. Tanaman padi pada umumnya dianjurkan untuk dipupuk urea $250 \mathrm{~kg} / \mathrm{ha}$, SP-36 $100 \mathrm{~kg} / \mathrm{ha}$, dan $\mathrm{KCl}$ $100 \mathrm{~kg} / \mathrm{ha}$ dengan asumsi bahwa kandungan N $46 \%$ pada urea, kandungan P2O5 $36 \%$ pada SP-36 dan kandungan $\mathrm{K}_{2} \mathrm{O} 57 \%$ pada $\mathrm{KCl}$ (BPTP, 2010).

Nilai sarana produksi pada usahatani padi sawah didaerah penelitian dapat dilihat pada tabel 6 . 
perbedaan biaya rata-rata sarana produksi benih antara petani penangkar benih dengan kelompok tani subur.

Sumber tenaga kerja yang digunakan berasal dari tenaga kerja dalam keluarga dan luar keluarga. Kegiatan-kegiatan di dalam usahatani padi sawah meliputi penyiangan, pemupukan dan pemanenan. Curahan tenaga untuk masing-masing kegiatan usahatani padi sawah dapat dilihat pada Tabel 7.

Tabel 7. Curahan Tenaga Kerja Rata-Rata Usahatani Padi Sawah di Daerah Penelitian pada Musim Tanam II, Tahun 2019

\begin{tabular}{|c|c|c|c|c|c|c|c|c|c|c|c|c|c|}
\hline \multirow{4}{*}{ No } & \multirow{4}{*}{ Jenis Kegiatan } & \multicolumn{12}{|c|}{ Curahan Tenaga Kerja (HKP) } \\
\hline & & \multicolumn{6}{|c|}{ Penangkar Benih } & \multicolumn{6}{|c|}{ Kelompok tani Subur } \\
\hline & & \multicolumn{3}{|c|}{ Per Petani $(0,5 \mathrm{Ha})$} & \multicolumn{3}{|c|}{ Per Hektar } & \multicolumn{3}{|c|}{ Per Petani $(0,38 \mathrm{Ha})$} & \multicolumn{3}{|c|}{ Per Hektar } \\
\hline & & TKDK & TKLK & Total & TKDK & TKLK & Total & TKDK & TKLK & Total & TKDK & TKLK & Total \\
\hline 1 & $\begin{array}{l}\text { Pengolahan } \\
\text { Lahan }\end{array}$ & 0,00 & 1,00 & 1,00 & 0,00 & 2,00 & 2,00 & 0,00 & 1,00 & 1,00 & 0,00 & 2,57 & 2,57 \\
\hline 2 & Penanaman & 0,00 & 8,00 & 8,00 & 0,00 & 16,00 & 16,00 & 0,00 & 8,00 & 8,00 & 0,00 & 20,58 & 20,58 \\
\hline 3 & Penyemaian & 0,50 & 0,00 & 0,50 & 1,00 & 0,00 & 1,00 & 0,39 & 0,00 & 0,39 & 1,00 & 0,00 & 1,00 \\
\hline 4 & Pemupukan & 3,00 & 0,00 & 3,00 & 4,00 & 0,00 & 4,00 & 1,56 & 0,00 & 1,56 & 4,00 & 0,00 & 4,00 \\
\hline 5 & Penyiangan & 0,00 & 30,60 & 30,60 & 0,00 & 61,20 & 61,20 & 0,00 & 23,33 & 23,33 & 0,00 & 60,00 & 60,00 \\
\hline 6 & Penyemprotan & 3,00 & 0,00 & 3,00 & 6,00 & 0,00 & 6,00 & 3,00 & 0,00 & 3,00 & 7,72 & 0,00 & 7,72 \\
\hline 7 & Pemanenan & 0,00 & 20,00 & 20,00 & 0,00 & 40,00 & 40,00 & 0,00 & 20,00 & 20,00 & 0,00 & 51,45 & 51,45 \\
\hline 8 & $\begin{array}{l}\text { Pengangkutan } \\
\text { Hasil }\end{array}$ & 0,00 & 5,00 & 5,00 & 0,00 & 10,00 & 10,00 & 0,00 & 0,00 & 0,00 & 0,00 & 0,00 & 0,00 \\
\hline & Total & 6,50 & 64,60 & 71,10 & 11,00 & 129,20 & 240,20 & 4,95 & 52,33 & 56,28 & 12,72 & 153,60 & 166,32 \\
\hline
\end{tabular}

Tabel 8. Nilai Tenaga Kerja Rata-Rata Usahatani Padi Sawah di Daerah Penelitian pada Musim Tanam II, Tahun 2019

\begin{tabular}{|c|c|c|c|c|c|c|c|c|c|c|c|c|c|}
\hline \multirow{4}{*}{ No } & \multirow{4}{*}{$\begin{array}{c}\text { Jenis } \\
\text { Kegiatan }\end{array}$} & \multicolumn{12}{|c|}{ Nilai Tenaga Kerja (Rp) } \\
\hline & & \multicolumn{6}{|c|}{ Penangkar Benih } & \multicolumn{6}{|c|}{ Kelompok tani Subur } \\
\hline & & \multicolumn{3}{|c|}{ Per Petani $(0,5 \mathrm{Ha})$} & \multicolumn{3}{|c|}{ Per Hektar } & \multicolumn{3}{|c|}{ Per Petani $(0,38 \mathrm{Ha})$} & \multicolumn{3}{|c|}{ Per Hektar } \\
\hline & & TKDK & TKLK & Total & TKDK & TKLK & Total & TKDK & TKLK & Total & TKDK & TKLK & Total \\
\hline 1 & $\begin{array}{l}\text { Pengolahan } \\
\text { Lahan }\end{array}$ & 0 & 312.500 & 312.500 & 0 & 625.000 & 625.000 & 0 & 242.969 & 242.969 & 0 & 625.000 & 625.000 \\
\hline 2 & Penanaman & 0 & 937.500 & 937.500 & 0 & 1.875 .000 & 1.875 .000 & 0 & 728.906 & 728.906 & 0 & 1.875 .000 & 1.875 .000 \\
\hline 3 & $\begin{array}{l}\text { Penyemaian } \\
\text { Pemunukan }\end{array}$ & 0 & 0 & 0 & 0 & 0 & 0 & 0 & 0 & 0 & 0 & 0 & 0 \\
\hline 4 & $\begin{array}{l}\text { Pemupukan } \\
\text { Penviangan }\end{array}$ & 0 & 0 & 0 & 0 & 0 & 0 & 0 & 0 & 0 & 0 & 0 & 0 \\
\hline 5 & $\begin{array}{l}\text { Penyiangan } \\
\text { Penvemprotan }\end{array}$ & 0 & 525.000 & 525.000 & 0 & 1.050 .000 & 1.050 .000 & 0 & 408.188 & 408.188 & 0 & 1.050 .000 & 1.050 .000 \\
\hline 6 & $\begin{array}{l}\text { Penyemprotan } \\
\text { Pemanenan }\end{array}$ & 0 & 0 & 0 & 0 & 0 & 0 & 0 & 0 & 0 & 0 & 0 & \\
\hline 7 & $\begin{array}{l}\text { Pemanenan } \\
\text { Pengangkutan }\end{array}$ & 0 & 1.250 .000 & 1.250 .000 & 0 & 2.500 .000 & 2.500 .000 & 0 & 971.875 & 971.875 & 0 & 2.500 .000 & 2.500 .000 \\
\hline 8 & $\begin{array}{l}\text { Pengangkutan } \\
\text { Hasil }\end{array}$ & 0 & 100.000 & 100.000 & 0 & 200.000 & 200.000 & 0 & 0 & 0 & 0 & 0 & 0 \\
\hline & Total & 0 & 3.125 .000 & 3.125 .000 & 0 & 6.250 .000 & 6.250 .000 & 0 & 2.351 .938 & 2.351 .938 & 0 & 6.050 .000 & 6.050 .000 \\
\hline
\end{tabular}

Tabel 7 menunjukkan bahwa jenis kegiatan yang paling banyak menyerap tenaga kerja adalah penyiangan. Curahan tenaga kerja untuk penyiangan petani penangkar benih sebesar 61,20 HKP/hektar/mt dan kelompok tani subur sebesar 60,00 HKP/hektar/mt. Diikuti oleh pemanenan petani penangkar benih sebesar 40,00 HKP/hektar/mt dan untuk pemanenan kelompok tani subur sebesar 51,45 HKP/hektar/mt. Curahan tenaga kerja terendah terdapat pada jenis kegiatan penyemaian. Curahan tenaga kerja untuk penyemaian petani penangkar benih sebesar 1,00 HKP/hektar/mt dan untuk penyemaian kelompok tani subur sebesar 1,00 HKP/hektar/mt.

Setiap jenis kegiatan usahatani padi sawah, tenaga kerja luar keluarga lebih banyak digunakan dibandingkan dengan tenaga kerja dalam keluarga. Penggunaan tenaga kerja luar keluarga lebih banyak dilakukan, karena setiap proses jenis kegiatan pada usahatani padi sawah membutuhkan waktu yang cepat, sehingga dapat mengejar waktu tanam, sehingga dibutuhkan tenaga kerja yang lebih besar. Pengolahan lahan dilakukan dengan menggunakan traktor. Nilai tenaga untuk masing-masing kegiatan usahatani padi sawah dapat dilihat pada Tabel 8 .

Tabel 8 menunjukkan bahwa nilai tenaga kerja dalam keluarga petani penangkar benih dan kelompok tani subur tidak dimasukkan kedalam biaya produksi karena sebagian besar petani memiliki lahan lebih kecil dari < 0,5 ha, sehingga masih tergolong petani kecil. Sedangkan nilai tenaga kerja luar keluarga petani penangkar sebesar Rp. 6.250.000/ ha/mt dan nilai tenaga kerja kelompok tani subur sebesar Rp. 6.050.000/ha/mt.

Perhitungan biaya penyusutan alat dengan menggunakan metode garis lurus (street line method) yaitu dinilai berdasarkan jumlah unit alat dikali dengan harga beli dan dibagi dengan umur ekonomis alat dan jumlah musim tanam dalam satu tahun. Untuk lebih jelasnya dapat disajikan dalam rumus 
matematis sebagai berikut :

Nilai ekonomis $(\mathrm{Rp} / \mathrm{thn})=$ $\frac{\text { Jumlah alat (unit) } \times \text { Harga beli }(\mathrm{Rp})}{\text { Umur ekonomis }}: 2$

Jenis peralatan yang digunakan dalam usahatani padi sawah di daerah penelitian terdiri dari: babat, pompa semprot, parang, cangkul dan ember. Besarnya biaya penyusutan alat dalam usahatani padi sawah di daerah penelitian dapat dilihat pada Tabel 9.

Tabel 9. Biaya Rata-Rata Penyusutan Alat pada Usahatani Padi Sawah di Daerah Penelitian pada Musim Tanam II, Tahun 2019

\begin{tabular}{|c|c|c|c|}
\hline \multirow{2}{*}{ No } & \multirow{2}{*}{ Jenis Alat } & \multicolumn{2}{|c|}{$\begin{array}{l}\text { Biaya Penyusutan } \\
\text { (Rp) }\end{array}$} \\
\hline & & $\begin{array}{c}\text { Petani } \\
\text { Penangkar }\end{array}$ & $\begin{array}{l}\text { Keltan } \\
\text { Subur }\end{array}$ \\
\hline 1 & Cangkul & 33.500 & 30.313 \\
\hline 2 & Pompa & 82.667 & 7.500 \\
\hline 3 & $\begin{array}{l}\text { Semprot } \\
\text { Sabit }\end{array}$ & 23.200 & 25.458 \\
\hline & Total & 139.267 & 63.271 \\
\hline
\end{tabular}

Dari tabel 9 dapat dilihat bahwa total biaya penyusutan alat usahatani padi penangkar benih sebesar Rp. 139.267/mt dan total biaya penyusutan alat usahatani kelompok tani subur sebesar Rp. $63.271 / \mathrm{mt}$. Besarnya biaya penyusutan alat ini sangat ditentukan oleh jumlah unit alat yang digunakan dalam pengelolaan usahatani padi sawah, di samping itu juga sangat dipengaruhi oleh umur ekonomis peralatan yang digunakan.

Biaya PBB/Ipeda yang harus dibayar oleh petani didasarkan pada luas lahan usahatani padi sawah tersebut. Penentuan biaya PBB/Ipeda biasanya ditentukan dalam per satuan hektar. Selanjutnya bila usahatani kurang dari satu hektar, besarnya biaya PBB yaitu jumlah biaya yang dibayarkan dalam satu hektar dikalikan dengan luas lahan yang diusahakan. Besarnya biaya Pajak Bumi dan Bangunan (PBB) sebesar Rp. 1.250.000 per ha/tahun.

Biaya total produksi dalam penelitian ini adalah seluruh biaya yang dikeluarkan oleh petani untuk usahatani padi sawah selama satu musim tanam mulai dari biaya tenaga kerja, benih, pupuk, pestisida, penyusutan alat dan biaya Pajak Bumi dan Bangunan (PBB) yang keseluruhannya dihitung dalam rupiah. Biaya total produksi yang dikeluarkan oleh petani usahatani padi sawah di daerah penelitian dapat dilihat pada Tabel 10.

Tabel 10. Biaya Total Produksi Usahatani Padi Sawah di Daerah Penelitian pada Musim Tanam II, Tahun 2019

\begin{tabular}{|l|l|l|c|}
\hline \multirow{2}{*}{ No } & \multirow{2}{*}{ Uraian } & \multicolumn{2}{|c|}{ Biaya Total Produksi (Rp) } \\
\cline { 3 - 4 } & & Petani Penangkar & Keltan Subur \\
\hline
\end{tabular}

\begin{tabular}{|c|c|c|c|c|c|}
\hline & & $\begin{array}{c}\text { Per } \\
\text { Petani } \\
(0,5 \mathrm{Ha})\end{array}$ & $\begin{array}{l}\text { Per } \\
\text { Hektar }\end{array}$ & $\begin{array}{c}\text { Per } \\
\text { Petani } \\
(0,38 \\
\mathrm{Ha})\end{array}$ & $\begin{array}{c}\text { Per } \\
\text { Hektar }\end{array}$ \\
\hline \multirow[t]{8}{*}{1} & Biaya & & & & \\
\hline & $\begin{array}{l}\text { Variab } \\
\text { el }\end{array}$ & 175.000 & 350.000 & 174.938 & 450.000 \\
\hline & -Benih & 950.000 & 1.900 .00 & 738.625 & 1.900 .00 \\
\hline & -Pupuk & 740.000 & 0 & 575.350 & 0 \\
\hline & & 3.125 .00 & 3.730 .00 & 2.351 .93 & 3.830 .00 \\
\hline & Pestisid & 0 & 0 & 8 & 0 \\
\hline & & & 6.250 .00 & & 6.050 .00 \\
\hline & & & & & \\
\hline \multirow[t]{10}{*}{2} & Tenaga & & & & \\
\hline & Kerja & & & & \\
\hline & Biaya & 139.267 & & 59.271 & \\
\hline & Tetap & 625.000 & & 485.938 & \\
\hline & - & 62.500 & 278.733 & 48.594 & 162.755 \\
\hline & Pnyusu & & 1.250 .00 & & 1.250 .00 \\
\hline & & & 0 & & 0 \\
\hline & -PBB & & 125.000 & & 125.000 \\
\hline & $\begin{array}{l}\text {-P- } \\
\text { airan }\end{array}$ & & & & \\
\hline & Total & $\begin{array}{c}5.816 .51 \\
7\end{array}$ & $\begin{array}{c}11.633 .7 \\
33\end{array}$ & $\begin{array}{c}4.434 .65 \\
2\end{array}$ & $\begin{array}{c}11.370 .9 \\
02\end{array}$ \\
\hline
\end{tabular}

Tabel 10 menunjukkan bahwa biaya total produksi pada usahatani penangkar benih sebesar Rp. $11.633 .733 / \mathrm{ha} / \mathrm{mt}$ dan biaya total produksi pada usahatani padi sawah kelompok tani subur sebesar Rp. 11.370.902/ha/mt. Besarnya biaya tunai yang dikeluarkan oleh petani dalam usahatani padi sawah dipengaruhi oleh benih, curahan tenaga kerja luar keluarga, jumlah pupuk, dan pestisida.

Sesuai dengan tujuan penelitian yaitu untuk melihat perbandingan biaya produksi usahatani padi sawah petani penangkar benih dengan petani kelompok tani subur, maka untuk membandingkan biaya produksi usahatani tersebut digunakan uji beda rata-rata dengan uji t.

Berdasasarkan uji t menggunakan SPSS uji rata rata (uji t) independent sampel t-test sebesar $1,801<2,009$. Sehingga dapat disimpulkan hipotesis $\mathrm{H}_{0}$ diterima dan $\mathrm{H}_{1}$ ditolak yang artinya biaya produksi petani padi sawah penangkar benih sama besar dibandingkan petani kelompok tani subur

Biaya produksi usahatani padi sawah petani penangkar benih dan petani kelompok tani subur tidak berbeda nyata. Hal ini disebabkan petani penangkar benih dan kelompok tani subur menggunakan sarana produksi dan tenaga kerja yang tidak jauh berbeda, sehingga biaya produksi usahatani juga relatif sama.

Dari hasil pemanenan tanaman padi sawah diperoleh dalam bentuk gabah yang selanjutnya dijual. Dari hasil penjualan gabah maka dapat dihitung besar penerimaan petani. Penerimaan usahatani padi sawah yang didapatkan oleh petani dikurangi biaya total produksi maka akan diperoleh pendapatan bersih dari usahatani padi sawah. Besarnya penerimaan dan pendapatan bersih rata-rata petani padi sawah di Desa Saentis, Kecamatan Percut Sei Tuan, Kabupaten Deli Serdang dapat dilihat pada Tabel 11. 
Tabel 11. Penerimaan dan Pendapatan Bersih Usahatani Padi Sawah Musim Tanam II di Daerah

\begin{tabular}{|c|c|c|c|c|c|}
\hline \multicolumn{6}{|c|}{ Penelitian, Tahun 2019 (Rp/mt) } \\
\hline \multirow{3}{*}{ No } & \multirow{3}{*}{ Uraian } & \multicolumn{4}{|c|}{ Jumlah (Rp) } \\
\hline & & \multicolumn{2}{|c|}{ Petani Penangkar } & \multicolumn{2}{|c|}{ Keltan Subur } \\
\hline & & $\begin{array}{l}\text { Per Petani } \\
(0,5 \mathrm{Ha})\end{array}$ & Per Hektar & $\begin{array}{l}\text { Per Petani } \\
(0,39 \mathrm{Ha})\end{array}$ & Per Hektar \\
\hline 1 & Penerimaan & 16.497 .000 & 32.994 .000 & 9.495 .878 & 24.348 .405 \\
\hline & Biaya Produksi & 5.816 .517 & 11.633 .733 & 4.434 .652 & 11.370 .902 \\
\hline 2 & Pendapatan Bersih & 10.680 .483 & 21.360 .266 & 5.061 .226 & 12.977 .502 \\
\hline
\end{tabular}

Tabel 11 menunjukkan bahwa besar penerimaan usahatani padi sawah penangkar benih sebesar Rp. 32.994.000 ha/mt dan besar penerimaan usahatani padi sawah kelompok tani subur sebesar Rp. 24.348.405 ha/mt. Besarnya penerimaan petani dipengaruhi oleh harga gabah kering yang dijual oleh petani. Harga gabah kering di daerah penelitian sebesar Rp. 4500/kg untuk petani penangkar dan Rp. 4300/kg untuk kelompok tani subur. Pendapatan bersih petani padi sawah diperoleh setelah dikurangi biaya produksi total. Besarnya pendapatan bersih usahatani padi sawah petani penangkar sebesar Rp. 21.360.266/ha/mt dan besar pendapatan bersih usahatani padi sawah kelompok subur sebesar Rp. 12.977.502/ha/mt.

Besarnya pendapatan bersih usahatani dipengaruhi tingkat produksi gabah kering dan yang dihasilkan dan harga gabah, serta juga dipengaruhi oleh besarnya biaya produksi usahatani. Tingkat pendapatan bersih usahatani di daerah penelitian tergolong besar karena di atas potensi pendapatan petani padi sawah oleh Dinas Pertanian Kabupaten Deli Serdang sebesar Rp. 9.705.600/ha/mt. Hal ini disebabkan harga gabah di daerah penelitian tergolong rendah yaitu $4.700 / \mathrm{kg}$. Dimana harga gabah kualitas terbesar terdapat di Kabupaten Deli Serdang dapat mencapai Rp. 5.300/kg. Harga terbesar tersebut berasal dari gabah kualitas Gabah Kering Panen (GKP) varietas Inpari 32. Harga gabah sangat ditentukan oleh kadar air gabah dan kadar hampa gabah yang dihasilkan. Menurut Dinas Pertanian Kabupaten Deli Serdang, gabah yang berkualitas baik adalah gabah yang memiliki kadar air sebesar 13,02\% dan kadar gabah sebesar 2,18\%.

Sesuai dengan tujuan penelitian yaitu untuk melihat perbandingan pendapatan bersih usahatani padi sawah petani penangkar benih dengan petani kelompok tani subur, maka untuk membandingkan pendapatan bersih usahatani tersebut digunakan uji beda rata-rata dengan uji t.

Berdasasarkan uji t menggunakan SPSS uji rata rata (uji t) independent sampel t-test sebesar $4,367>2,009$. Sehingga dapat disimpulkan hipotesis $\mathrm{H}_{0}$ ditolak dan $\mathrm{H}_{1}$ diterima yang artinya pendapatan bersih petani padi sawah penangkar benih lebih besar dibandingkan petani kelompok tani subur.

Pendapatan usahatani padi sawah petani penangkar benih lebih besar dibandingkan dengan petani kelompok tani subur. Hal ini disebabkan petani penangkar benih memiliki tingkat produksi yang lebih besar. Dengan harga gabah yang tidak jauh berbeda, maka Produktivitas yang semakin besar akan meningkatkan pendapatan bersih usahatani.

\section{KESIMPULAN}

1. Produktivitas usahatani padi sawah petani penangkar benih lebih besar dibandingkan dengan petani kelompok tani subur. Produktivitas petani penangkar benih sebesar 7,34 ton/ha, sedangkan petani kelompok tani subur sebesar 5,78 ton/ha.

2. Biaya produksi usahatani padi sawah petani penangkar benih lebih besar dibandingkan dengan petani kelompok tani subur. Biaya produksi petani penangkar benih sebesar Rp. 11.633.733/ha/mt, sedangkan petani kelompok tani subur sebesar Rp. 11.370.902/ha/mt.

3. Pendapatan bersih usahatani padi sawah petani penangkar benih lebih besar dibandingkan dengan petani kelompok tani subur. Pendapatan bersih usahatani padi sawah petani penangkar benih sebesar Rp. 21.360.266/ha/mt, sedangkan petani kelompok tani subur sebesar Rp. $12.977 .502 / \mathrm{ha} / \mathrm{mt}$.

\section{SARAN}

1. Bagi petani lain dapat dijadikan sebagai alternatif usahatani padi sawah yang menguntungkan, sehingga dapat dipilih penggunaan benih yang lebih terjamin mutunya untuk memperoleh produktivitas yang lebih besar.

2. Bagi peneliti lain yang ingin melanjutkan penelitian ini dengan mengkombinasikan dengan penerapan komponen-komponen lain dari pendekatan pengelolaan tanaman dan sumber daya terpadu.

\section{DAFTAR PUSTAKA}

BPS. 1988-2018. Provinsi Sumatera Utara Dalam Angka 1988-2018. BPS Sumatera Utara. Medan. 
Sumodiningrat, Gunawan. Membangun Perekonomian Rakyat. Pustaka Pelajar 1988, Yogyakarta.

Soekartawi. 1995. Agribisnis Teori dan Aplikasinya. PT Raja Grafindo Persada. Jakarta.

Putro, SN. 2010. "Pengaruh Pertumbuhan Ekonomi, Pendapatan Asli Daerah dan Dana Alokasi Umum Terhadap Pengalokasian Anggaran Belanja Modal (Study Kasus pada Kabupaten/Kota di Provinsi Jawa Tengah)." Skripsi. Fakultas Pertanian. Universtias Esa Unggul, Jakarta. 